\title{
No princípio era o mythos: articulações entre Mito, Psicanálise e Linguagem
}

\author{
Ana Amália Torres Souza \\ Universidade Federal do Rio Grande do Norte \\ Zeferino Jesus Barbosa Rocha \\ Universidade Católica de Pernambuco
}

\begin{abstract}
Resumo
À guisa de uma reflexão introdutória, são apresentadas, no início do presente trabalho, algumas das principais concepções de mito, surgidas no decurso da História do Pensamento e sistematizadas por diversos autores. $\mathrm{O}$ objetivo principal do artigo, porém, é dar um destaque especial ao que Freud e Lacan disseram sobre o mito, bem como à sua articulação com a Psicanálise, destacando a relação estreita de ambos com a Linguagem. Quando se afirma que o inconsciente é estruturado como uma linguagem por meio da ação significante $\mathrm{e}$ se constata que o mito é significante, pode-se dizer que o inconsciente estrutura-se numa dimensão mítica, no linguajar do mito. Sendo assim, o mito é um saber que nos atravessa sem que o saibamos, assim como o inconsciente. Concluímos que o mito, linguagem literária por excelência, tem a função de dizer o indizível, fornecendo-lhe um pouco de organização e proporcionando um resgate necessário à fala do inconsciente.
\end{abstract}

Palavras-chave: mito; linguagem; Psicanálise.

\begin{abstract}
The beginning was the mythos: articulations between Myth, Psychoanalysis and Language. In the present work are presented the main conceptions of myth, appeared during History of thoughts and systematized for several authors. It was given a special stand out to what Freud and Lacan said about myth and also about its articulation with psychoanalysis and we emphasize the strait relation between them and the language. When its affirmed that the unconscious is structures with language through a meaning action, and its confirmed that the myth is meaningful, it can be said that the unconscious structure itself is in a mythic dimension, in myth language. This way the myth is a knowledge that passes through us without our own perception as the unconscious. We conclude that the myth, literary language for excellence, has the function to tell the unspeakable, giving us a little bit of organization and providing a necessary rescue to the unconscious language.
\end{abstract}

Keywords: myth; language; psychoanalysis.

O mito é o nada que é tudo

O mesmo sol que abre os céus

é um mito brilhante e mudo -

O corpo morto de Deus, vivo e desnudo.

Os versos de Fernando Pessoa (1989) ilustram a complexidade de se falar sobre o mito e nos convidam à difícil incumbência de penetrar no espaço do indizível e do inexplicável. Para tanto, vamos apresentar, à guisa de uma reflexão introdutória, algumas entre as principais concepções de mito, surgidas no decurso da História do Pensamento e, seguindo o roteiro traçado por Abbagnano (2000), destacaremos três significados do termo mito, possíveis de serem distintos e historicamente situados.

Na Antiguidade clássica, o Mythos opunha-se ao Lógos, à Razão e ao discurso filosófico de natureza racional, o qual era tido como verdadeiro, e, como tal, contraposto às narrativas míticas, pilares de sustentação das sociedades chamadas arcaicas. Todavia, a filosofia penetrava no campo do mito ao se propor a estudar questões tipicamente humanas, como, por exemplo, a busca das origens e a ordem do mundo. Saindo do âmbito daquilo que não pode ser transformado em conceito, o discurso filosófico racionalizou e laicizou a narrativa mítica, procurando superá-la e deixando-a como coisa de um passado primitivo.

Dessa forma, sucede-se uma mudança nos paradigmas a partir dos pressupostos filosóficos que fornecem "modelos para a compreensão da gênese e da regulação do mundo" (Vernant, $1962 / 1987$, p. 119). O mito deixa de ser a explicação para as coisas do cotidiano e o cotidiano passa, então, a explicar as construções míticas. Uma tempestade, por exemplo, deixa de ser vista como um acesso de fúria dos deuses e passa a ser 
um fenômeno natural que não justificaria uma crença na ira divina.

Substitui-se, então, a linguagem mítica, toma-se distância de uma Mitopoiése e insere-se numa outra, a linguagem do discurso filosófico. A origem dessa transformação remete-nos ao mito do surgimento do oráculo de Delfos, narrado por Menard (1985):

$\mathrm{Na}$ origem, a resposta do deus, tal qual a davam os sacerdotes, era sempre formulada em versos; mas tendo tido um filósofo a idéia de perguntar por que o deus da poesia se exprimia em maus versos, a ironia foi repetida por todos, e o deus passou a falar somente em prosa, o que lhe aumentou o prestígio (p. 30).

Nesta perspectiva, o surgimento da filosofia, na Grécia, marca, de acordo com a maioria dos estudiosos, o declínio do pensamento mítico. Apesar de Walter Burkert (1991) ser um dos autores que se opõe a essa idéia, afirmando que a filosofia nunca se emancipou do mito completamente, os demais apontam para o fato da ordem humana passar a ser definida por si mesma, traduzindo-se em fórmulas acessíveis à compreensão do homem, na qual passou a ser aplicada "a lei do número e da medida" (Vernant, 1962/1987, p. 150).

O Mito, em uma segunda concepção, é situado em um plano diferente da lógica científica, mas é dotado de igual valor por ser "uma forma autônoma de pensamento ou de vida" (Abbagnano, 2000 , p. 673) e possui uma lógica própria, podendo, assim, ser considerado uma forma de fazer filosófico.

O Romantismo foi uma das vertentes teóricas que adotaram esse novo conceito de mito. Essa doutrina do mito também foi acolhida e desenvolvida por outros filósofos e sociólogos, dentre eles, destaca-se Cassirer. No volume II de sua obra, Filosofia de las formas simbólicas (1964/1998), este autor trata do pensamento mítico, apresentando, inicialmente, a relação da filosofia com o mito e várias posturas adotadas por diversos filósofos, ao tomá-lo como objeto de reflexão.

Ao adotar alguns pressupostos de Hegel, Cassirer (1964/1998) afirma que "o mito se converte em um problema para a filosofia, à medida que nele se manifesta uma direção originária do espírito, um modo independente de configuração da consciência" (p. 20) ${ }^{1}$. Ele constata que a genuína e verdadeira unidade do espírito está representada pela tríade: linguagem, arte e mito.

O mito teria, então, uma realidade peculiar para a consciência, sendo uma forma de vida característica e original, encontrando-se, assim como a vida, situada na linha divisória entre o meramente objetivo e o meramente subjetivo, sendo uma esfera indiferenciada entre ambos. Ademais, ele é considerado como um patrimônio espiritual da humanidade, cuja unidade deve ser explicada pela unidade da alma humana (Cassirer, 1964/1998).

Dessa forma, os mitos resultariam de experiências humanas coletivas, sem que seus produtores tivessem consciência da autoria deles, pois são projeções das interpretações do mundo interior e das impressões do mundo exterior, transformadas em imagens que não se resumem a metáforas ou representações, mas são expressões da própria realidade.

Cassirer (1964/1998) defende, ainda, a tese de que o homem deveria ser definido não como um animal rationale, mas como um animal symbolicum e que não só o conhecimento científico é um conhecimento simbólico, mas todo conhecimento e toda relação do homem com o mundo acontecem no âmbito das diversas formas simbólicas. Neste sentido, a linguagem, o mundo mítico-religioso e a arte apresentam-se como outras tantas formas simbólicas particulares.

Nesta perspectiva, Gilbert Durand, em seus livros Imaginação Simbólica (1988) e As estruturas antropológicas do Imaginário (1997), trata do universo do simbólico e do relacionamento deste com a civilização. Ele defende a assertiva de que "o que importa no mito não é exclusivamente o encadeamento da narrativa, mas também o sentido simbólico dos termos" (Durand, 1997, p. 356), e acrescenta, ainda, que o mito tem a mesma estrutura da música, com um ritmo próprio e com a função não de contar, mas, sim, de repetir como o refrão de uma canção.

Sendo assim, para compreender o mito nessa perspectiva, é necessário estar prevenido do que fala Cassirer, em seu livro Antropologia Filosófica (1944/1972a), ou seja, "não podemos reduzir o mito a certos elementos estáticos fixos, mas procurar apreendê-lo em sua vida interior, em sua mobilidade e versatilidade, em seu princípio dinâmico" (Cassirer, 1944/1972a, p. 127).

A terceira concepção de mito fundamenta-se na moderna teoria sociológica, tendo Fraser e Malinowski como precursores. Para eles, o mito tem a função única de dar continuidade à cultura, estando intimamente ligada à natureza da tradição, à atitude humana em relação ao passado. Dessa maneira, o mito não está ligado só às sociedades primeiras, mas é indispensável a qualquer cultura, sendo necessário "estudá-lo em relação à função que exerce na sociedade humana" (Abbagnano, 2000, p. 675)

Ao que parece, essa terceira linha de pensamento não se opõe à segunda, mas focaliza aspectos diferentes do mito, que foram elaborados por vários autores. Dentre eles, Lévi-Strauss (1973/1996) tem um lugar de destaque. Par ele, cada grupo social expressa, em suas construções míticas, suas atitudes em relação ao mundo, bem como as maneiras de resolver os problemas da existência. Ele defende que o mito não se sujeita a "nenhuma regra de lógica ou de continuidade" (Lévi-Strauss, 1973/1996, p. 239) e é considerado como tal, enquanto for assim percebido e reconhecido.

Cabe ressaltar também os estudos de Morin (1986). Este distingue dois modos de conhecimento e de ação: o simbólico/ mitológico/mágico e o empírico/técnico/racional. Para ele, existem complementaridade e possibilidade de coexistência e interação entre esses modelos. Afinal, "toda a renúncia ao conhecimento empírico/técnico/racional conduziria os humanos à morte e toda a renúncia às suas crenças fundamentais desintegraria a sua sociedade" (Morin, 1986, p. 144).

No primeiro, símbolo, mito e magia implicam-se e fundemse. O símbolo, com sua característica autônoma, alimenta o pensamento mitológico e a magia alimenta-se de ambos, ao mesmo tempo que os alimenta. Ademais, ao partir da idéia de Cassirer, Morin afirma que, como o símbolo, o mito possui um coagulum de sentido, vários níveis de verdade, mas, ao mesmo tempo em que ele engloba a esfera do símbolo, a 
ultrapassa, tecendo conjuntamente o simbólico, o imaginário e, eventualmente, o real.

A partir desse entendimento, Morin (1986) avança pontuando as imbricações e complementaridades entre mito e razão e a presença deste primeiro na sociedade contemporânea, conforme trecho abaixo:

Paradoxalmente, é na sua pretensão a reger e guiar a humanidade que a Razão e a Ciência se vão achar clandestinamente parasitadas pelo mito... Muitos trabalhos de inspirações muito diversas (entre os quais os meus) convergem para sublinhar a presença oculta do mito no âmago do nosso mundo contemporâneo e, mais profundamente, foi desde o século XIX que a filosofia descobriu a importância do mito e interrogou o seu mistério (Morin, 1986, p. 145).

Para esse autor, as mitologias são narrativas e é, nesse âmbito, então, que "o mistério do mito invade aquele que o considera a partir do exterior" (Morin, 1986, p. 146), fazendo-o considerar o mito como algo referente àquilo que é vivido no interior, como verdade. É importante ressaltar a proposta de Morin (1986) de que o mito é algo inseparável da linguagem fazendo jus à sua raiz etimológica, pois Mythos significa discurso. Mythos e Lógos possuem antagonismos, ao mesmo tempo em que tem complementaridades, interferindo um no outro.

Contudo, a verdade do mito não obedece à lógica nem da verdade empírica, nem da verdade científica. Ela é intuída, não necessita de provas para ser aceita e diz a realidade. $\mathrm{O}$ mito não é uma mentira, pois é verdadeiro para quem vive e é uma forma espontânea do homem situar-se no mundo, elevá-lo a outra esfera, ao transcendente, oferecendo valores absolutos e paradigmas às atividades humanas, ocupando-se de tudo "o que suscita a interrogação, a curiosidade, a necessidade e a aspiração" (Morin, 1986, p. 150).

Ainda nessa linha de pensamento, Eliade (1963/2000), constata que "o mito é uma realidade cultural complexa, que pode ser abordada e interpretada em perspectivas múltiplas e complementares... Conta uma história sagrada, relata um acontecimento que teve lugar no tempo primordial, o tempo fabuloso dos "começos"” (p. 12).

Este mitólogo nota que o tempo do mito é o tempo fabuloso, tempo passado, mas sempre presente e, portanto, não separado do nosso tempo, falando daquilo que se manifestou plenamente, revelando sua atividade criadora e descrevendo as diversas e freqüentemente dramáticas eclosões do sagrado no Mundo.

$\mathrm{O}$ mito funda-se em um modelo exemplar, fixando-o e propiciando fundamentos para o mundo, bem como direcionando atividades humanas significativas, conferindo valores e significados à existência. Afinal, é ao mito que cabe preservar a verdadeira história, a história da condição humana, falando de realidades e do modo como elas passaram a existir.

Em resumo, conhecer os mitos é aprender o segredo da origem das coisas. Por outras palavras, "aprende-se não só como as coisas passaram a existir, mas também onde as encontrar e como fazê-las ressurgir quando elas desaparecem" (Eliade, 1963/2000, p. 19).

\section{Psicanálise e Mito: o percurso de Freud e Lacan}

A Psicanálise foi descoberta a partir de três experiências fundamentais de Freud. A primeira foi a experiência clínica com seus clientes, a segunda foi a sua auto-análise e a terceira sua experiência com a alma humana por meio dos mitos 2 .

Há muito já se sabe da contaminação mútua entre Mito e Psicanálise, uma vez que muitos estudos e comentários foram feitos a esse respeito, dentre eles, a obra de Azevedo (2004) em seu livro Mito e Psicanálise. Sendo assim, achamos conveniente pôr em destaque o percurso de Freud e Lacan em suas respectivas abordagens sobre o mito.

Todavia, não nos propomos, neste momento, a promover um diálogo entre Mito e Psicanálise, analisando as influências de um sobre o outro, mas, sim, seguir os rastros das concepções freudianas e lacanianas de mito, articulando-as à compreensão dos outros autores, mencionados anteriormente.

Iniciaremos, portanto, com Freud que, segundo Azoubel Neto (1993), contribuiu para o estudo do mito por compreendêlo como um fenômeno psíquico vivo e pulsante, ajudando, dessa forma, na ampliação desse campo de investigação e estabelecendo uma ligação deste com a teoria psicanalítica, retomando a discussão sobre a importância do mito no funcionamento normal e patológico do psiquismo humano. Nas palavras de Azoubel Neto (1993):

A psicanálise redescobriu o mito, retomou o seu estudo e fê-lo
através de um método de trabalho próprio, um método que
constitui em si um processo de resgate. Localizou a presença
do mito como uma condição real, atuante e atual no incon-
sciente (p. 15).

Para Eliade (1963/2000), o foco de todo mito é o começo das coisas, a sua origem. Mesmo os mitos conhecidos como escatológicos dirigem sua atenção não para o fim em si, mas para um novo começo. Sendo assim, a relação da Psicanálise com a mitologia está justamente no fato de ambos se interessarem pelas origens e pelos primórdios do humano. Essa idéia é reforçada por Jones (1989), quando assevera que "em toda sua vida, [Freud] provavelmente foi mais absorvido pelo grande problema de como o homem veio a ser homem do que por qualquer outro problema" (p. 314).

Ao se debruçar sobre a história pessoal do sujeito, em sua primeira infância, a teoria freudiana valoriza a experiência do nascimento, as assim chamadas primeiras relações de objeto e afirma que a criança vive em um tempo mítico e paradisíaco, à procura de uma resposta para a curiosidade que lhe desperta a origem dos bebês. No âmbito dessa relação entre a teoria freudiana e o mito, Eliade (1963/2000) afirma:

É por isso que o inconsciente apresenta a estrutura de uma mitologia privada. Podemos ir ainda mais longe e afirmar não só que o inconsciente é 'mitológico', mas também que alguns dos seus conteúdos estão carregados de valores cósmicos, isto é, que eles refletem as modalidades, os processos e o destino da vida e da matéria viva. Podemos até dizer que o único contato real do homem moderno com a sacralidade cósmica se efetua através do inconsciente, quer se trate dos seus sonhos e da sua vida imaginária, quer das criações que surgem do inconsciente (poesia, jogos, espetáculos, etc.) (p. 68-69). 
Anzieu (2006), afirma que, na obra de Freud, existe um caminho em três etapas, em que se desenvolve sua abordagem da mitologia. A primeira etapa é representada pelo texto "A interpretação dos sonhos" (Freud, 1900/1987a), no qual ele atesta que a mitologia pode fornecer uma ajuda para entender alguns processos inconscientes. No mito, assim como nos sonhos, projetam-se elementos inconscientes que, em seus elementos significantes, podem referir-se a variadas coisas, a depender do sujeito e de sua história. Sonhar é ter acesso ao funcionamento psíquico e este, por sua vez, possui setores de aplicabilidade na patologia e nas produções culturais, sendo que, nestas últimas, o mito ganha destaque. Se os sonhos são os mitos do indivíduo, os mitos seriam, então, os sonhos da humanidade, exprimindo os seus desejos.

A segunda etapa é desenvolvida em "Totem e Tabu" (Freud, 1913/1987b), na qual Freud redireciona seu olhar para os ritos e crenças sobre o totemismo e o animismo, ressaltando que os mitos são recapitulações desses ritos e criando o mito da horda primitiva que serviu de fio condutor para o entendimento psicanalítico da vida coletiva. No mito, as representações negadas ao homem são projetadas sobre os deuses e a eles atribuídas.

A terceira etapa culmina com "Moisés e o Monoteísmo" (Freud,1939/1987c), em que Freud afirma que a religião judaicocristã forneceu e continua fornecendo à nossa civilização alguns dos mitos subjacentes a ela. No comentário de Anzieu (2006):

Em uma palavra, os mitos falam aos homens não sobre o mundo exterior, mas sobre o mundo interior, não sobre a realidade, mas sobre as fantasias, bem como sobre os desejos e as angústias a eles ligadas... O mito reproduzia os pavores do homem primitivo diante dos perigos de um mundo exterior ameaçador e as tentativas históricas reais por meio das quais alguns grandes homens tinham permitido aos mortais vencer esses medos (p. 61-62).

Freud se ocupou da relação entre mito e fantasia, que liga representações fantasmáticas a representações mitológicas. Essa percepção pode ser explicitada, por exemplo, no seu texto "Um paralelo mitológico com uma obsessão visual" (Freud, 1916/1987d). De acordo com Anzieu (2006), o mito cumpre uma função de prova da existência do inconsciente e de suas características de universalidade, intemporalidade e indestrutibilidade. A figuração simbólica do mito recebe relevo na obra freudiana como uma função de representação, pois o que é recalcado precisa ser simbolizado, revelando o conteúdo latente do inconsciente.

Posteriormente, Freud vai tomando certa distância dos estudos sobre o mito e aproxima-se dos ritos, mas até o fim, em seus escritos, a exemplo dos mitólogos, ele fala da sabedoria ensinada pelos mitos e de sua dupla lição: a da proibição e, também, a do desejo (Anzieu, 2006).

Em sua própria perspectiva, Lacan (1969-1970/1992) afirma que a função do mito é a de liberar

o povo de uma pergunta que dizima os seus melhores, querendo responder ao que se apresenta como enigma, quer dizer, àquilo que se presume ser sustentado por esse ser ambíguo que é a esfinge, onde se encarna, falando propriamente, uma dupla disposição por ser feita, tal como o semi-dizer, de dois semi-corpos (p. 113).

Ele analisa a estrutura e as relações do mito com a linguagem, propondo a sua aplicabilidade à teoria psicanalítica e construindo o que denominou de o mito individual do neurótico (Lacan, 1953/2008). Neste texto, o autor segue as proposições deixadas por Lévi-Strauss, o qual propõe o conceito de mito individual, ou seja, a redução de uma gama de mitos ao agrupá-los em determinados moldes, construídos com base em suas funções elementares. Baseado nesse princípio, Lacan afirma:

Todo mito é uma procura do tempo perdido. Esta forma moderna da técnica xamanística, que é a psicanálise, tira, pois, seus caracteres particulares do fato de que, na civilização mecânica, não há mais lugar para o tempo mítico, senão no próprio homem (Lévi-Strauss, 1958/1985, p. 224).

Lacan define o mito como uma expressão imaginária das relações fundamentais características do modo de ser humano em uma determinada época e termina por aproximá-lo da vivência neurótica. Ele é um legado cultural e social, mas que se inscreve individualmente e contempla, ao mesmo tempo, um aspecto coletivo e singular, pondo em destaque os paradoxos da subjetividade situada e construída na fronteira entre o eu e o outro. Esta constatação aproxima ainda mais mito e Psicanálise a partir do processo de estruturação neurótica. Como escreve Lévi-Strauss (1958/1985):

Vimos que a única diferença entre os dois métodos [Psicanálise e Xamanismo] que sobreviveria à descoberta de um substrato fisiológico das neuroses diria respeito à origem do mito, encontrado, num caso, como um tesouro individual, e recebido, noutro, da tradição coletiva (p. 233).

Referindo-se ao mito, Lacan (1956-1957/1995) dá destaque ao complexo de Édipo, colocando-o no centro da experiência psicanalítica e realçando o quarteto mítico que serve de pilar para a construção do mito individual do neurótico. $\mathrm{O}$ mito de Édipo muito mais do que estruturar o conceito freudiano de Complexo de Édipo permitiu a Lacan visualizar as bases do fundamento da neurose. Ele é formado pelo desejo incestuoso pela mãe, pela interdição do pai e os efeitos decorrentes disso, pela proliferação luxuriosa dos sintomas e, por último, pela morte. Com suas próprias palavras:

Este progresso do imaginário ao simbólico constitui uma organização do imaginário em mito, ou, pelo menos, está a caminho de uma construção mítica verdadeira, isto é, coletiva, e nos lembra disso por todos os lados, a ponto mesmo de evocar para nós os sistemas de parentesco (Lacan, 1956-1957/1995, p. 273).

Assim, cada um constrói seu mito individual, ou complexo, a partir de elementos retirados de seu próprio passado, os quais irão compor os mitemas. Este termo do mitólogo Lévi-Strauss (1958/1985) refere-se a uma repetição de seqüências no mito. São unidades de construção mítica que se (re)significarão ao serem combinados em cada narrativa produzida pelo sujeito. O mito é visto, desse modo, como uma forma de narrativa que possui algo de atemporal e inesgotável, tendo também a noção 
de uma estrutura e, por isso mesmo, podendo ser reencontrado e reaplicado. Lacan segue a proposição de Lévi-Strauss (1958/1985) de que o mito tem uma estrutura ao mesmo tempo sincrônica (não-histórica, momentânea) e diacrônica (histórica, permanente). Desta forma, é a permanência da estrutura ao longo do tempo que lhe traz a possibilidade de mudança dentro da própria estrutura.

Ao salientar os aspectos estruturais do mito, Lacan (19561957/1995) considera-o como uma organização do imaginário, que, por meio da palavra, tenta exprimir a verdade, não podendo, contudo, apreendê-la toda e, assim, constrói um discurso imaginário sobre a mesma, que é o próprio mito. Contudo, vale ressaltar que Lacan, diferentemente de Freud, localiza a estrutura para além do mito afirmando que o "mito, é isso, a tentativa de dar forma épica ao que se opera da estrutura" (Lacan, 1974/1993, p. 55). No entanto, não é nosso propósito, no presente trabalho, aprofundar a relação entre estrutura e mito.

A verdade não pode ser toda dita e/ou conhecida. Sendo assim, o mito (re)vela a impossibilidade da verdade, ao mesmo tempo que indica o seu lugar. Portanto,

o mito é o que dá uma formulação discursiva a algo que não pode ser transmitido na definição da verdade, porque a definição da verdade só pode se apoiar sobre si mesma, e é na medida em que a fala progride que ela a constitui" podendo ser expressa apenas de 'forma mítica' (Lacan, 1953/2008, p. 13).

Apesar de ser de caráter ficcional, o mito necessariamente não se separa da noção de verdade. Pelo contrário, Lacan (19561957/1995) pontua que a verdade se encontra velada no próprio mito como aquilo que está por trás da ficção, agregada a ela. É o que se constata na citação abaixo:

Essa ficção mantém uma relação regular com alguma coisa que está sempre implicada por trás dela, e da qual ela porta, realmente, a mensagem formalmente indicada, a saber, a verdade. Aí está uma coisa que não pode ser separada do mito... A verdade tem uma estrutura, se podemos dizer, de ficção (Lacan, 1956-1957/1995, p. 258 -259).

Partindo dessas colocações de Lacan sobre a verdade, Boyer (1971/1977) afirma que o mito tem a verdade como causa. Ademais, a verdade de que o mito trata, repete temas básicos ligados à existência do sujeito, por exemplo, a vida e a morte, o aparecimento do que não existia e o desaparecimento do que existia e o fato dele ser sujeito de um sexo (Carreira, 2001).

Por uma Mythopoiése...

O mito é a metáfora remetida ao infinito, ... [ao] seu lugar de ser no alhures do discurso (Rabant, 1971/1977, p. 37)

A partir do arcabouço teórico, que pode ser chamado de campo freudiano, Lacan se propõe a construir uma teoria baseada nessa arquitetura, privilegiando dois pólos, a linguagem e a transferência, para promover um retorno a Freud no sentido de restaurar a "originalidade freudiana da experiência do inconsciente, sob a égide de uma hipótese tão audaciosa como esta: o inconsciente é estruturado como uma linguagem" (Dor, 2003, p. 12-13). A introdução de alguns conceitos da lingüística no campo teórico da Psicanálise proporcionou a Lacan acrescer novos construtos teóricos (Dor, 2003). Ao centrar suas colaborações no fundamento da palavra, ele circunscreve e reescreve a teoria psicanalítica.

Desse modo, emergindo essas substituições significantes num redobrar do sujeito na palavra, pode ser constatado que "o sujeito não somente é causa da linguagem, mas também causado por ela" (Dor, 2003, p. 107), a qual denota uma representação, uma máscara que o aliena em seu próprio discurso. Tal alienação, com o significante e pelo significante, é definida como a refenda do sujeito que se torna oculto de si mesmo pela dimensão da linguagem. Ele jamais poderá falar, por si mesmo, a verdade de seu desejo, a não ser pela ordem de seu discurso.

Em "Função e campo da fala e da linguagem em Psicanálise", Lacan (1956/1998) inaugura a idéia de inconsciente apoiado na teoria do significante, sendo este um significante puro, no qual se marca a clivagem do sujeito. Segundo Roudinesco (1998), este conceito tem suas bases na lingüística de Saussure e nas construções de Lévi-Strauss. Ao inverter a lógica saussuriana, Lacan dá destaque ao significante. Letra esta, na qual se marca o assentamento do inconsciente na linguagem. É a expressão involuntária do ser falante e arruma-se em cadeia. Portanto, a linguagem é colocada em lugar de primazia e como condição do inconsciente.

Nesta perspectiva, assim como a Psicanálise, o mito também possui relação estreita com a linguagem. Com um viés diferente do adotado por Lacan, Cassirer (1944/1972a) enfatiza a ligação do mito com a linguagem:

Linguagem e mito são parentes próximos. Nos primeiros estádios da cultura humana suas relações são tão estreitas e, tão evidente sua cooperação, que se torna quase impossível separá-los. São dois brotos diferentes da mesma e única raiz. Sempre que encontramos o homem, vemo-lo na posse do dom da linguagem sob a influência da função mito-criadora (p. 175).

Cabe salientar que não se pretende nivelar mito e linguagem, despojando-os de suas particularidades, mas ressaltar a reciprocidade de um e de outro, o que proporciona a ambos, uma renovação. O pensar mítico e o lingüístico determinam suas estruturas, dominados pelos mesmos motivos espirituais, sujeitos a análogas leis de desenvolvimento, sendo que o primeiro é considerado a mãe-terra de todas as formas simbólicas e a chave que abre a "compreensão dos conceitos originários da linguagem" (Cassirer, 1925/1972b, p. 54).

O mito é influenciado pela linguagem. Cassirer (1925/1972a) atesta as afirmações de Max Muller, declarando que "tudo o que chamamos de mito, é, segundo seu parecer, algo condicionado e mediado pela atividade da linguagem: é, na verdade, o resultado de uma deficiência lingüística originária, de uma debilidade inerente à linguagem" (p. 18).

Max Muller (1876, citado por Cassirer, 1964/1998) articula a linguagem ao pensamento, tentando provar que a primeira causa para a criação das noções míticas foi a ambigüidade da palavra, sendo a metáfora a responsável por estabelecer os laços para uni-los. Segundo ele, a linguagem exerce seu poder 
sobre o pensamento, sendo uma sombra projetada sobre ele. A mitologia, por sua vez, seria a comprovação dessa relação por ser uma necessidade inerente à linguagem e uma forma externa de pensamento.

Assim, o Mito não só é condicionado e mediado pela atividade da linguagem, mas é resultado de uma deficiência lingüística originária, de uma debilidade inerente à linguagem, ou seja, ele está no lugar daquilo que falha, do que escapa à linguagem, como nos afirma Lévi-Strauss (1958/1985), “em nada ajuda cotejar o mito e a linguagem: o mito faz parte integrante da língua; é pela palavra que ele se nos dá a conhecer, ele provém do discurso... O mito está, simultaneamente, na linguagem e além dela" (p. 240).

Nessa articulação, pode-se fazer, com Azevedo (2004), uma ponte entre o mito e o inconsciente estruturado como uma linguagem de Lacan, colocando a dimensão mítica em congruência com a dimensão inconsciente e apontando para as características comuns em suas estruturas. A linguagem, então, é a base da intersecção entre mito e Psicanálise.

Cabe salientar a analogia (semelhança na dessemelhança) encontrada entre a proposta lacaniana de significante e a proposta de Lévi-Strauss de mitema. Lacan (1956-1957/1995) diz que estas unidades, ou elementos, do mito têm um funcionamento estrutural que pode ser comparado ao funcionamento da estrutura da linguagem, e afirma que o mito tem o poder de manejar e ser manejado pelo significante, encarnando a instância do significante e o introduzindo como instrumento na cadeia das coisas naturais. Em resumo, mito é um significante, e mais, um significante tal como entendido por Lacan.

O mito "não é algo somente da ordem do significado, do conteúdo, mas igualmente diz respeito a como esse significado se constrói, a uma lógica que preside a articulação significante" (Azevedo, 2004, p. 12). Sendo assim, o mito tem valor significante, pois é "alguma coisa que, em si, não significa nada, mas carrega, certamente, toda a ordem de significação" (Lacan, 1956-1957/1995, p. 261).

Dessa maneira, a característica de desenfreamento do significante está presente no mito, o que pode ser expresso em sua exigência por interpretação, precisando ser sempre (re) significado e podendo ser considerado como uma estrutura folheada, na qual, o sentido não se encontra em seus elementos isolados, mas sim em sua composição que varia e permite que o sentido sempre possa ser outro.

Sendo assim, não é o conteúdo da narrativa que define o mito, mas, sim, sua estrutura que a precede e possibilita (Carreira, 2001). No dizer de Lévi-Strauss (1958/1985):

A substância do mito não se encontra nem no estilo, nem no modo de narração, nem em sintaxe, mas na história que é relatada. $\mathrm{O}$ mito é linguagem, mas uma linguagem que tem lugar em um nível muito elevado, e aonde o sentido chega, se é lícito dizer, a decolar do fundamento lingüístico sobre o qual começou rolando (p. 242)

De acordo com Azevedo (2004), o mito é uma intersecção, uma confluência entre o contínuo e o descontínuo, entre o universal e o singular, entre a estrutura e as atualizações, assim como a linguagem que se estrutura em dois eixos: a língua (estruturada, invariável) e a fala (atualização pulsante e singular da língua). É essa estrutura histórica e não-histórica do mito que explica o porquê dele fazer parte desses domínios.

Em decorrência dos estudos sobre o signo lingüístico, Saussure (1915/1995) incrementa sua teoria com a distinção de um duplo corte no sistema da linguagem, fazendo desdobramentos no discurso em duas direções: a das seleções e a das combinações. A primeira está articulada ao eixo paradigmático, estabelecendo uma relação de similitude dos elementos significativos entre os signos, e refere-se à linguagem e à metáfora. A segunda estruturase sobre o eixo sintagmático, estabelecendo uma relação de contigüidade, ou seja, de articulação das unidades lingüísticas e refere-se à fala e à metonímia.

O signo lingüístico e o corte sob dois eixos possibilitam examinar duas de suas propriedades, o valor do signo e as construções metafóricas e metonímicas. Em primeiro lugar, o valor delimita o signo através de seu contexto, expresso em função de todos os outros signos, proporcionando sentido. Essa noção de valor afirma a linguagem como sistema estrutural, tornando os signos significativos não só pelo seu conteúdo, mas pelas relações de oposição que mantêm entre si na cadeia falada, dando-lhes uma identidade significativa.

A partir das proposições saussurianas sobre fluxos de pensamentos e fluxos de sons e sua afirmação de que o significante é inseparável do signo lingüístico em sua totalidade, Lacan, primeiro, nos fala de fluxo de significados e de significantes e, depois, inverte o signo lingüístico. É aí que surge o conceito de ponto-de-estofo que nada mais é do que aquilo por meio do qual o significante se associa ao significado na cadeia discursiva.

Tendo em vista o estatuto de significante do mito, tem-se sua estrutura organizada também em cadeia. No dizer de LéviStrauss, "O mito se desenvolverá como em espiral" (1958/1985, p. 265). As seqüências míticas, ou seja, os mitemas são formas vazias que, apesar de manterem uma relação constante entre si, são preenchidas de maneiras variáveis, em virtude das suas combinações nas narrativas. Contudo, Carreira (2001) adverte que

a narrativa não é o mito, pois cada narrativa é apenas uma de suas possibilidades de organização, é apenas um paradigma. $\mathrm{O}$ mito é justamente este horizonte de possibilidades, não sendo acessível enquanto tal, mas sim por partes, nas narrativas que aludem a ele e lhe dão uma forma (versão eletrônica).

Portanto, o que importa, no mito, não são seus elementos considerados isoladamente, mas a relação entre eles, e, mais, os feixes de relações, as formas de combinações, a harmonia. Durand $(1988,1997)$ compara-o com a música, que, estruturada em uma partitura, se organiza sincronicamente (leitura-notas) e diacronicamente (seqüência-ritmo), o que pode aludir à movimentação do significante por meio de processos metafóricos e metonímicos.

Em seu livro Linguagem e Mito, Cassirer (1925/1972b) atribui à origem do mito, a inerente ambigüidade e equivocidade da linguagem, as suas formas metafóricas e seus modos indiretos de descrição que geram seu "próprio mundo significativo" 
(Cassirer, 1925/1972b, p. 22). Para ele, a unidade e a diferença entre mito e linguagem se dão por meio do entendimento de metáfora, podendo ser esta definida como o

vínculo intelectual entre a linguagem e o mito... a autêntica fonte da metáfora é procurada nas construções da linguagem, ora, na fantasia mítica; ora, é a palavra que, por seu caráter originariamente metafórico, deve gerar a metáfora mítica e prover-lhe constantemente novos alimentos, ora, ao contrário, considerase o caráter metafórico das palavras tão-somente um produto indireto, um patrimônio que a linguagem recebeu do mito e que ela tem como um feudo dele (Cassirer, 1925/1972b, p. 102).

Na Antigüidade, a metáfora era uma questão de necessidade. No pensamento mítico, existe uma indissociabilidade entre a palavra que designa e a própria coisa designada. O homem mítico identificava seu nome com o seu próprio ser, por isso, proferir o nome de alguém significava torná-lo presente. A palavra tinha poder para evocar o mágico, sendo ela mesma mágica por si. Para a lingüística a função da linguagem é a comunicação, mas para a Psicanálise é a evocação. A fala como ato de discurso, e não como ato de fonação, implica dirigir uma mensagem para alguém, demandando uma resposta. Neste sentido, é através da fala que se realiza a função da linguagem e não o contrário.

Assim, a transposição de uma palavra, levada de um conceito a outro, mostrava-se mais interessante do que a criação de um novo conceito por meio de um velho nome. Posteriormente, o homem percebe que a linguagem e a realidade se relacionam de formas diferentes, que a palavra não pode alterar o rumo da natureza, nem evocar os deuses, mas que possui sentido e poder. O Logos se torna, então, o "primeiro princípio do conhecimento humano" (Cassirer, 1925/1972b, p. 178).

Na perspectiva lacaniana, por meio da noção de metáfora e metonímia, podemos compreender a idéia de supremacia do significante e sua relação com as formações inconscientes. $\mathrm{O}$ processo metafórico consiste em designar alguma coisa por meio do nome de uma outra coisa, em relação de similaridade e de substituição significante. Aqui, a noção de significante aproxima-se, mais uma vez, da noção de inconsciente, sendo algo que, como afirma Dor (2003), está “sempre aí, mas também e ao mesmo tempo, sempre alhures" (p. 45).

Contudo, na perspectiva lacaniana, não há metáfora sem metonímia e vice-versa. Essas duas técnicas do significante sustentam-se na produção de uma metáfora inaugural, que é a base e o suporte para ambas. Referimo-nos à metáfora do Nome-do-Pai, fundamentada nas construções freudianas em torno do mito de Édipo. Assim, procuramos destacar o mito em seus movimentos metafóricos e sua aproximação com a noção lacaniana de inconsciente.

Neste aspecto, Lacan (1956-1957/1995), remetendo ao caso Hans, afirma que, apesar de nem todos os complexos de Édipo precisarem passar por uma tal construção mítica, "é certo que eles necessitam realizar a mesma plenitude na transposição simbólica" (p. 273). Portanto, o mito é mais do que um símbolo, é o próprio simbólico. Como acrescenta Carreira (2001):

Por ser uma estrutura sobre a qual o sentido desliza, o mito possui uma função importante. A técnica narrativa mítica parte de uma estrutura simbólica que pode reconstruir uma multiplicidade de experiências reais e, mais ainda, passar para a expressão verbal algo caótico e contraditório que, por ser da ordem do real, não pode ser resolvido sem o simbólico. Podemos dizer que o mito fala de uma verdade impossível de ser dita de outra maneira que não por esta alusão: como estrutura simbólica, ele permite vestir o real com o imaginário (versão eletrônica).

Nesse contexto, a noção de inconsciente aproxima-se, ainda mais, da noção de mito, por meio do conceito do significante e do simbólico. Poderíamos, então, perguntar se a estrutura do mito seria a de um significante, movimentando-se a partir de processos metafóricos e metonímicos, sendo, nesse ponto, análoga à estruturação do inconsciente. Poderíamos indagar, também, se assim como o inconsciente é representado no mito, este seria representado no inconsciente.

Quando se afirma que o inconsciente é estruturado como uma linguagem por meio da ação significante e se constata que o mito é significante, pode-se dizer que o inconsciente estrutura-se numa dimensão mítica, no linguajar do mito. Sendo assim, o mito é um saber que nos atravessa sem que o saibamos, assim como o inconsciente, um saber que não se sabe, que se sabe.

Ademais, como bem define Calvino (1971/1977):

O inconsciente é o mar do não-dizível, do que foi expulso da linguagem, abandonado depois de antigas proibições; o inconsciente fala - nos lapsos, nos sonhos, nas associações espontâneas - através das palavras emprestadas, dos símbolos roubados, dos contrabandos lingüísticos, até que a literatura resgate estes territórios e os anexe à linguagem da véspera ( $\mathrm{p}$. 77 , grifo nosso).

Dessa forma, a função do mito é dizer o indizível e, assim, fornecer-lhe um pouco de organização. Ao ser a linguagem literária por excelência, o discurso mito-poético proporciona o resgate necessário à fala do inconsciente, tendo como função fornecer "o significante do impossível" (Lacan, 1953/2008, p. 91).

\section{Referências}

Abbagnano, N. (2000). Dicionário de Filosofia. São Paulo: Martins Fontes. Anzieu, D. (2006). Psicanalisar. São Paulo: Idéias e Letras.

Azevedo, A. V. (2004). Mito e Psicanálise. Rio de Janeiro: Jorge Zahar.

Azoubel Neto, D. (1993). Mito e Psicanálise: estudos psicanalíticos sobre formas primitivas de pensamento. São Paulo: Papirus.

Boyer, P. (1977). O mito no texto. In G. Luccioni (Org.), Atualidade do mito (pp. 81-88). São Paulo: Duas Cidades. (Publicado originalmente em 1971)

Burkert, W. (1991). Mito e mitologia. Lisboa: Edições 70.

Calvino, I. (1977). A combinatória e o mito na arte da narrativa. In G. Luccioni (Org.), Atualidade do mito (pp. 75- 80). São Paulo: Duas Cidades. (Publicado originalmente em 1971)

Carreira, A. F. (2001). O mito individual como estrutura subjetiva básica Psicologia: ciência e profissão, 21(3), 58-69. Recuperado em 22 de novembro, 2009, de <http://pepsic.bvs-psi.org.br/scielo.php?script=sci arttext\&pid $=\mathrm{S} 1414-98932001000300008 \& \operatorname{lng}=\mathrm{pt} \& \mathrm{nrm}=\mathrm{iso}>$.

Cassirer, E. (1972a). Antropologia filosófica. São Paulo: Mestre Jou. (Publicado originalmente em 1944)

Cassirer, E. (1972b). Linguagem e Mito. São Paulo: Perspectiva. (Publicado originalmente em 1925) 
Cassirer, E. (1998). Filosofia de las formas simbólicas. México: Fondo de Cultura Econômica. (Publicado originalmente em 1964)

Dor, J. (2003). Introdução à leitura de Lacan. Porto Alegre: Artes Médicas.

Durand, G. (1988). A imaginação simbólica. São Paulo: Cultrix.

Durand, G. (1997). As estruturas antropológicas do Imaginário. São Paulo: Martins Fontes.

Eliade, M. (2000). Aspecto do mito. Lisboa: Edições 70. (Publicado originalmente em 1963)

Freud, S. (1987a). A Interpretação dos sonhos. In S. Freud, Obras psicológicas completas (J. Salomão, Trad.). (versão eletrônica). Rio de Janeiro: Imago. (Publicado originalmente em 1900).

Freud, S. (1987b). Totem e Tabu. In S. Freud, Obras psicológicas completas (J. Salomão, Trad.). (versão eletrônica). Rio de Janeiro: Imago. (Publicado originalmente em 1913).

Freud, S. (1987c). Moisés e o Monoteísmo. In S. Freud, Obras psicológicas: completas (J. Salomão, Trad.). (versão eletrônica). Rio de Janeiro: Imago. (Publicado originalmente em 1939).

Freud, S. (1987d). Um paralelo mitológico com uma obsessão visual. In S. Freud, Obras psicológicas: completas (J. Salomão, Trad.). (versão eletrônica). Rio de Janeiro: Imago. (Publicado originalmente em 1916).

Jones, E. (1989). A vida e a obra de Sigmund Freud. Rio de Janeiro: Imago.

Lacan, J. (1992). Seminário 17: o avesso da psicanálise. Rio de Janeiro: Jorge Zahar. (Publicado originalmente em 1969-1970)

Lacan, J. (1993). Televisão. Rio de Janeiro: Jorge Zahar. (Publicado originalmente em 1974).

Lacan, J. (1995). Seminário 4: A relação de objeto. Rio de Janeiro: Jorge Zahar. (Publicado originalmente em 1956-1957)

Lacan, J. (1998). Função e campo da fala e da linguagem em Psicanálise. In J. Lacan, Escritos (pp. 238-324). Rio de Janeiro: Jorge Zahar. (Publicado originalmente em 1956).

Lacan, J. (2008). O mito Individual do Neurótico. Rio de Janeiro: Jorge Zahar. (Publicado originalmente em 1953)

Lévi-Strauss, C. (1985). Antropologia Estrutural. (2a ed.). Rio de Janeiro: Edições Tempo Brasileiro. (Publicado originalmente em 1958)

Lévi-Strauss, C. (1996). Antropologia Estrutural Dois (5a ed.). (C. Ratz e E. Pires, Trad.). Rio de Janeiro: Tempo Brasileiro. (Publicado originalmente em 1973).

Menard, R. (1985). Mitologia Greco-Romana. São Paulo: Fittipaldi Editores.

Morin, E. (1986). O método III: o conhecimento do conhecimento. Lisboa: Publicações Europa-América, LDA.

Pessoa, F. (1989). Guardador de rebanho e outros poemas. São Paulo: Círculo do livro.

Rabant, C. (1977). O mito no porvir (re) começa... In G. Luccioni (Org.), Atualidade do mito (pp. 29-40). São Paulo: Duas Cidades. (Publicado originalmente em 1971)

Saussure, F. (1995). Curso de lingüística geral. São Paulo: Editora Cultrix. (Publicado originalmente em 1915)

Vernant, J. P. (1987). Origem do pensamento grego. (5a ed.). Lisboa: Teorema. (Publicado originalmente em 1962)

1.Tradução da autora.

2. Esta frase é de Didier Anzieu e foi transmitida a Zeferino Jesus Barbosa Rocha, em uma de suas aulas na Faculdade de Filosofia de Nanterre (Universidade de Paris-X), durante o ano escolar de 1967-1968.

Ana Amália Torres Souza, doutoranda em Psicobiologia pela Universidade Federal do Rio Grande do Norte (UFRN), é bolsista de doutorado do Conselho Nacional de Pesquisa de Desenvolvimento Científico e Tecnológico (CNPq). Endereço para correspondência: Rua Humberto Monte, 1062. Capim Macio. Natal/ RN. Tel: (84) 8853-0337.E-mail: adiscipula@hotmail.com

ZeferinodeJesus Barbosa Rocha, doutoremPsicologiapelaUniversidadedeParis X, éprofessoradjuntodo Mestrado em Psicologia na Universidade Católica de Pernambuco (UNICAP-PE). E-mail: zephyrinus@globo.com 